\title{
KONTRIBUSI KEBIJAKAN DIVIDEN DALAM EFEKTIVITAS KEUANGAN DAN IMPLIKASINYA PADA NILAI PERUSAHAAN
}

\author{
${ }^{1}$ Jeudi Agustina T. Parulian Sianturi ${ }^{\bowtie},{ }^{2}$ Diana Hasyim, ${ }^{1}$ Marlyna Infryanty Hutapea, \\ ${ }^{1}$ Rasmulia Sembiring, ${ }^{1}$ Alfredo Simatupang, ${ }^{3}$ Dianty Putri Purba \\ ${ }^{1}$ Universitas Methodist Indonesia, Medan, Indonesia, ${ }^{2}$ Universitas Negeri Medan, Indonesia, \\ ${ }^{3}$ Universitas Prima Indonesia, Medan, Indonesia \\ Email: jeudisianturi@yahoo.co.id
}

DOI: https://doi.org/10.46880/methoda.Vol11No2.pp115-126

\begin{abstract}
This study aims to examine the contribution of dividend policy in mediating the effect of financial effectiveness on firm value. The sample used is a manufacturing company listed on the Indonesia Stock Exchange for the period from 2010-2017 with reference to the predetermined sample criteria. Empirical results prove that dividend policy partially mediates the effect of financial effectiveness (ROA) and firm size (Ln TA) on firm value (tobin q). This study provides additional support for agency theory and signaling theory. Keyword: Profitability, Firm Size, Dividend Policy, Firm Value.
\end{abstract}

\begin{abstract}
ABSTRAK
Studi ini bertujuan untuk menguji konstribusi kebijakan dividen dalam memediasi pengaruh efektivitas keuangan terhadap nilai perusahaan. Sampel yang digunakan adalah perusahaan manufaktur yang tercatat di Bursa Efek Indonesia untuk periode waktu mulai dari 2010-2017 dengan mengacu pada kriteria sampel yang telah ditetapkan. Hasil empiris membuktikan bahwa kebijakan dividen memediasi pengaruh efektivitas keuangan (ROA) dan ukuran perusahaan (Ln TA) terhadap nilai perusahaan (tobin q) secara parsial. Penelitian ini memberikan tambahan dukungan terhadap teori agensi dan teori signalling. Kata Kunci: Profitabilitas, Ukuran Perusahaan, Kebijakan Dividen, Nilai Perusahaan.
\end{abstract}

\section{PENDAHULUAN}

Penelitian ini dilatarbelakangi oleh adanya kesenjangan hasil penelitian dari pengaruh efektivitas keuangan terhadap nilai perusahaan. Beberapa peneliti (Carlson dan Bathala, 1997; Chen dan Steiner, 2000; López-Iturriaga dan Rodríguez-Sanz, 2001; Uchida, 2006; Chen dan Chen, 2011; Gill dan Obradovich, 2012; Hermuningsih, 2014; Sucuahi dan Cambarihan, 2016; Iswajuni et al., 2018) menemukan adanya pengaruh positif dari efektivitas keuangan (profitabilitas) terhadap nilai perusahaan. Sementara beberapa peneliti lainnya (Fama dan French, 1998; Kaaro, 2002; Suranta dan Merdistuti, 2004; Suharli, 2006; Carningsih, 2008; Kodongo et al., 2015; Tamrin et al., 2017; Rizki et al., 2018) mendapatkan hasil yang berbeda.
Inkonsistensi hasil penelitian yang ditemukan di atas, dapat menjelaskan beberapa hal. Pertama, efektivitas keuangan pada dasarnya memiliki peran dalam menjelaskan nilai perusahaan. Kedua, pengaruh efektivitas keuangan terhadap nilai perusahaan yang belum konklusif mengindikasikan bahwa peran atau pengaruh efektivitas keuangan terhadap nilai perusahaan menjadi lebih kompleks dibandingkan sebuah hubungan langsung yang sederhana. Ada kecenderungan bahwa hubungan antar variabel tersebut bersifat tidak langsung, yaitu melalui suatu variabel mediasi. Dengan kata lain, efektivitas keuangan mempengaruhi nilai perusahaan melalui suatu hubungan yang tidak langsung. Dengan demikian diperlukan pengkajian lebih lanjut mengenai proses penciptaan nilai perusahaan melalui efektivitas keuangan. 
Penelitian ini mengusulkan kebijakan dividen sebagai variabel intervening untuk menjelaskan pengaruh efektivitas keuangan terhadap nilai perusahaan atau mengatasi kesenjangan hasil penelitian di atas. Untuk menganalisis hubungan tidak langsung antar variabel maka penelitian ini dibagi ke dalam lima bagian. Pertama, pendahuluan. Kedua, tinjauan pustaka dan pengembangan hipotesis. Bagian ketiga, metode penelitian dan keempat hasil empiris, serta terakhir merupakan kesimpulan.

\section{LITERATUR REVIEW}

\section{Pengaruh Efektivitas Keuangan terhadap Nilai Perusahaan}

Efektivitas keuangan yang diproksikan dengan return on asset (Wajeetongratana et al., 2019) menunjukkan kemampuan perusahaan dalam menghasilkan laba dengan mempergunakan sumber-sumber yang ada dalam perusahaan tersebut (Sartono, 2014). Jika kapabilitas laba dapat terus konsisten maka perusahaan akan mampu menjadikan investasi modal sebagai model yang dapat menggambarkan tingkat keuntungan perusahaan kepada para investor yang ada di pasar dengan karakteristik asimetri informasi. Situasi sedemikian sejalan dengan teori signalling yang pertama kali dikembangkan oleh Spence (1973) yang kemudian dirangkum oleh Megginson (1997) menjadi empat pilar model utama model sinyal yang dikenal dalam literatur keuangan (Ghozali, 2020).

Salah satu model tersebut adalah model sinyal investasi korporasi yang menjelaskan bahwa investasi modal merupakan suatu sinyal yang mahal bagi manajer dan sulit untuk ditiru oleh para pesaing dari perusahaan yang memberikan sinyal. Dikatakan mahal karena manajer dari perusahaan tersebut mampu mengeluarkan dana yang besar untuk kegiatan investasi. Sementara pesaing perusahaan belum tentu mampu meniru apa yang dilakukan oleh perusahaan pemberi sinyal ini. Memang bisa saja manajer dari perusahaan pemberi sinyal mengorbankan profit dengan harapan bahwa perusahaan ini mampu menunjukkan keunggulan yang membedakannya dengan perusahaan lain kepada para investor. Ketika para investor menangkap sinyal ini maka akan memberikan sinyal yang positif dan memberikan masa depan yang cerah bagi perusahaan. Artinya perusahaan tersebut akan menjadi incaran dari para investor yang akan menanamkan investasinya. Semakin banyak investor yang menanamkan modalnya maka secara tidak langsung akan dapat menaikkan harga saham yang juga berdampak pada meningkatnya nilai perusahaan. Konsep teoretis tersebut juga didukung oleh beberapa hasil empiris sebelumnya (Sabrin et al., 2016; Rosikah et al., 2018; Ayuba et al., 2019) yang menunjukkan terdapat pengaruh positif dari efektivitas keuangan (ROA) terhadap nilai perusahaan (tobin's q). Dengan demikian dapat dihipotesiskan:

\section{Hipotesis 1: Efektivitas Keuangan berpengaruh positif terhadap nilai perusahaan}

\section{Pengaruh Efektivitas Keuangan terhadap Kebijakan Dividen}

Salah satu faktor yang mempengaruhi kebijakan dividen adalah profitabilitas (Ardestani et al., 2013). Artinya semakin tinggi profitabilitas suatu perusahaan mengindikasikan kemampuannya untuk membayar dividen kepada para pemegang saham. Oleh karena itu, pihak manajemen akan berupaya untuk terus meningkatkan kemampuan perusahaan dalam menghasilkan laba sehingga dapat meningkatkan kemampuan perusahaan dalam membayar dividen kepada pemegang saham. Pernyataan ini sejalan dengan teori signalling yang menyatakan bahwa laba yang dihasilkan perusahaan mengandung sinyal informasi yang positif mengenai adanya pembayaran dividen (Leland dan Pyle, 1977). Frame work teoretis ini juga dijustifikasi dalam beberapa penelitian lainnya (Abor dan Bokpin, 2010; Arko et al., 2014) yang menemukan pengaruh positif dari efektivitas keuangan terhadap kebijakan dividen. Berdasarkan kerangka teoretis dan riset empiris di atas maka dapat dihipotesiskan:

Hipotesis 2: Efektivitas Keuangan berpengaruh positif terhadap Kebijakan Dividen 


\section{Kebijakan Dividen Memediasi Pengaruh Efektivitas Keuangan terhadap Nilai Perusahaan}

Salah satu keputusan keuangan jangka panjang adalah kebijakan dividen. Keputusan ini merupakan suatu kebijakan yang harus diambil oleh manajer dalam hal seberapa besar laba yang akan ditahan dan seberapa besar laba yang akan dibagikan kepada pemegang saham dalam bentuk dividen. Keputusan ini masih merupakan suatu perdebatan sampai saat ini sehingga menjadi salah satu dilema dalam pengambilan keputusan: apakah akan membayar dividen atau ditahan sebagai laba ditahan untuk kegiatan investasi yang mampu meningkatkan pertumbuhan perusahaan. Namun dari perspektif teori agensi, adanya pemisahan kepemilikan dan pengelolaan perusahaan menimbulkan konflik agensi antara agen dan prinsipal. Untuk menyikapi konflik ini maka diperlukan suatu mekanisme atau alat monitoring untuk menyelaraskan kepentingan agen dan prinsipal yang salah satunya melalui kebijakan dividen, yaitu dalam bentuk pembayaran dividen kepada pemegang saham. Pemberian dividen ini diharapkan dapat berperan dalam mereduksi tindakan-tindakan oportunistik manajerial dari penggunaan sumber dana internal ke dalam kegiatan-kegiatan investasi yang tidak menghasilkan net present value (NPV) positif. Dengan demikian, pengambilan keputusan manajer akan berfokus pada maksimalisasi nilai perusahaan. Mengacu pada teori agensi ini maka dapat disimpulkan bahwa kebijakan dividen dapat mengatasi ketidakefisienan penggunaan dana internal oleh tindakan oportunistik manajerial sehingga peningkatan nilai perusahaan dapat optimal. Dari perspektif yang berbeda, teori signalling memberikan pandangan bahwa pembayaran dividen memberikan sinyal positif sehingga pasar akan memberikan penilaian yang positif terhadap harga saham perusahaan yang pada akhirnya meningkatkan nilai perusahaan.

Berdasarkan pernyataan di atas, terdapat efek tidak langsung dari pengaruh efektivitas keuangan terhadap nilai perusahaan melalui kebijakan dividen. Hal ini juga didukung oleh sejumlah penelitian empiris (Aivazian et al., 2003; Amidu dan Abor, 2006; Abor dan Bokpin, 2010; Arko et al., 2014; Pattiruhu dan PAAIS, 2020) yang membuktikan efektivitas keuangan berpengaruh positif terhadap kebijakan dividen dan di lain pihak penelitian lainnya (Anton dan Cuza, 2016) membuktikan terdapat pengaruh positif kebijakan dividen terhadap nilai perusahaan. Dengan demikian dapat dihipotesiskan:

Hipotesis 3: Kebijakan dividen memediasi pengaruh efektivitas keuangan terhadap nilai perusahaan.

\section{Pengaruh Ukuran Perusahaan terhadap Nilai Perusahaan}

Ukuran perusahaan merupakan salah satu faktor lainnya yang mempengaruhi nilai perusahaan. Dikatakan demikian karena skala perusahaan yang semakin besar memberikan sinyal yang positif dalam hal kemudahan akses untuk mendapatkan sumber dana eksternal sehingga perusahaan lebih fleksibel dalam menangkap peluang-peluang investasi yang memberikan NPV (net present value) positif, yang pada akhirnya dapat meningkatkan nilai perusahaan.

Pernyataan ini sejalan dengan teori signalling yang menyatakan bahwa informasi tentang kinerja perusahaan dengan skala besar dipandang lebih baik dibandingkan dengan perusahaan yang berskala kecil, yang diukur dari total aktiva. Keadaan ini dianggap oleh investor bahwa berinvestasi pada perusahaan dengan skala besar akan memberikan risiko yang lebih kecil sehingga akan banyak investor yang mempertimbangkan untuk memiliki saham perusahaan tersebut. Akibatnya likuiditas saham menjadi meningkat yang pada akhirnya berdampak pada peningkatan nilai perusahaan. Beberapa dukungan riset empiris membuktikan (Gill dan Obradovich, 2012; Prasetyorini, 2013; Pratama dan Wiksuana, 2016) bahwa terdapat pengaruh positif dari ukuran perusahaan terhadap nilai perusahaan.

Berdasarkan kajian teoretis dan hasil empiris di atas maka dapat dihipotesiskan:

Hipotesis 4: Ukuran Perusahaan berpengaruh positif terhadap nilai perusahaan 


\section{Pengaruh Ukuran Perusahaan terhadap Kebijakan Dividen}

Menurut teori sinyal yaitu model sinyal dividen (Meggison, 1997), ukuran perusahaan merupakan salah satu faktor yang mempengaruhi kebijakan dividen. Dalam teori tersebut dijabarkan bagaimana mahalnya bagi manajemen mengenai pembayaran dividen. Dari sudut pandang manajemen dikatakan mahal karena pembayaran dividen akan mengurangi dana perusahaan dalam melakukan kegiatan investasi. Walaupun demikian bagi perusahaan besar, pembayaran dividen tetap dilakukan karena dapat memberikan sinyal positif bagi pasar karena dipersepsikan perusahaan memiliki keunggulan yang membedakan dengan perusahaan lainnya. Oleh karena itu, dapat disimpulkan bahwa ukuran perusahaan memiliki peran dalam menjelaskan kebijakan dividen. Beberapa penelitian empiris sebelumnya (Aivazian et al., 2003; Ho, 2003) menemukan bukti bahwa terdapat pengaruh positif ukuran perusahaan terhadap kebijakan dividen. Dengan demikian dapat dihipotesiskan:

Hipotesis 5: Ukuran Perusahaan berpengaruh positif terhadap Kebijakan Dividen

\section{Kebijakan Dividen Memediasi Pengaruh Ukuran Perusahaan terhadap Nilai Perusahaan}

Teori agensi (Jensen dan Meckling, 1976) memberikan pandangan bahwa perusahaan dengan skala besar memiliki biaya agensi yang lebih tinggi daripada perusahaan dengan skala kecil. Dalam rangka mereduksi biaya ini, lebih lanjut teori agensi menyatakan bahwa pengungkapan informasi merupakan salah satu mekanisme yang efektif karena pengungkapan informasi dapat memberikan sinyal positif bagi pasar. Salah satu informasi tersebut berupa pengumuman pembayaran dividen. Mengacu kepada model sinyal dividen, ukuran perusahaan merupakan salah satu faktor yang mempengaruhi kebijakan dividen. Dalam arti semakin besar skala perusahaan mengindikasikan bahwa sumber daya perusahaan juga besar sehingga berkemampuan untuk membayar dividen. Di lain pihak, berdasarkan model sinyal dividen (Megginson, 1997) bahwa pembayaran dividen menunjukkan keunggulan yang membedakan perusahaan pemberi sinyal dengan perusahaan lainnya sehingga memberikan pengaruh yang positif terhadap nilai perusahaan. Teori ini sejalan dengan relevance dividend theory (Livoreka et al., 2014) yang menyatakan bahwa pembayaran dividen berpengaruh terhadap nilai perusahaan. Berdasarkan pandangan teori-teori tersebut di atas, dapat disimpulkan bahwa terdapat efek berjenjang dari pengaruh ukuran perusahaan terhadap nilai perusahaan melalui kebijakan dividen. Sejumlah penemuan empiris (Aivazian et al., 2003; Ho, 2003) juga membuktikan adanya pengaruh yang positif dari ukuran perusahaan terhadap kebijakan dividen dan di lain pihak hasil empiris lainnya (Anton dan Cuza, 2016) menemukan bukti terdapat pengaruh kebijakan dividen terhadap nilai perusahaan. Dengan demikian dapat dihipotesiskan:

Hipotesis 6: Kebijakan dividen memediasi pengaruh efektivitas keuangan terhadap nilai perusahaan

\section{Pengaruh Kebijakan Dividen terhadap Nilai Perusahaan}

Dividend relevance theory atau bird in the hand theory dari Gordon dan Lintner (Livoreka et al., 2014)) menyatakan bahwa biaya modal sendiri perusahaan akan naik jika presentase laba yang dibayarkan kepada pemegang saham dalam bentuk DPR (dividend payout ratio) yang rendah karena investor lebih menyenangi pembayaran dividen saat ini daripada di masa yang akan datang walaupun dividend yield-nya tinggi. Dengan kata lain, perusahaan harus memberikan seluruh labanya dalam bentuk dividen. Dengan demikian, biaya modal perusahaan akan rendah yang pada akhirnya nilai perusahaan akan meningkat. Pandangan teoretis ini sejalan dengan beberapa teori lainnya yaitu teori signalling (Spence, 1973) dan model sinyal dividen (Megginson, 1997).

Intinya beberapa teori tersebut di atas menjelaskan bahwa dengan adanya kebijakan dividen sebagai salah satu mekanisme monitoring maka diharapkan dapat 
memitimigasi masalah agensi sehingga dapat meningkatkan nilai dari suatu perusahaan.

Framework teoretis tersebut dijustifikasi dalam sejumlah penelitian empiris (Anton dan Cuza, 2016; Giriati, 2016) yang menemukan bukti adanya pengaruh positif dari kebijakan dividen terhadap nilai perusahaan. Berdasarkan kajian teoretis dan penemuan empiris tersebut di atas maka dapat dihipotesiskan:
Hipotesis 7: Kebijakan Dividen berpengaruh positif terhadap nilai perusahaan

Bertitik tolak dari tinjauan literatur dan pengembangan hipotesis di atas maka dapat disusun suatu model teoretis seperti yang terlihat pada gambar 1 berikut ini:

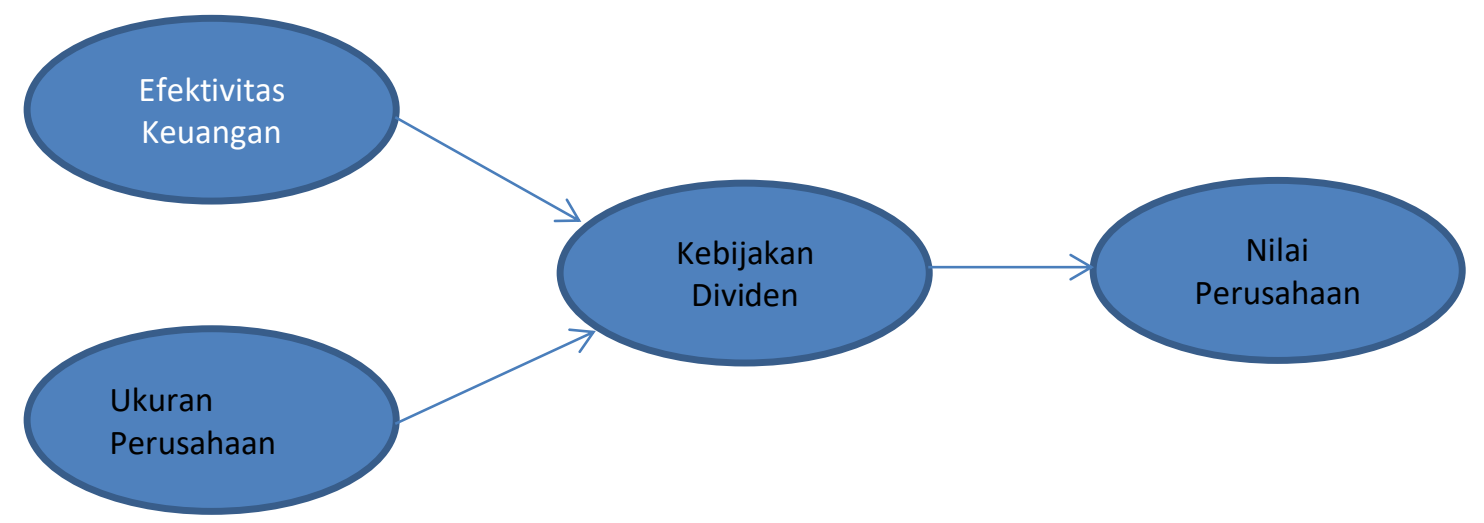

Gambar 1. Model Teoretis

\section{METODOLOGI}

\section{Data Sampel Penelitian}

Sampel pada penelitian ini terdiri dari 51 perusahaan manufaktur yang telah tercatat di Bursa Efek Indonesia dengan periode waktu 2010-2017. Sampel yang terpilih dilakukan melalui tehnik purposive sampling dengan kriteria: 1) perusahaan secara rutin menyajikan dan mempublikasikan laporan keuangan dan tahunan mulai dari tahun 2010 hingga 2017; 2) perusahaan memiliki informasi yang relevan dengan variabel yang akan diteliti pada laporan keuangan tahunan, seperti: efektivitas keuangan (profitabilitas), ukuran perusahaan (Ln Total asset), rasio pembayaran dividen (DPR), dan nilai perusahaan (tobin's q) secara lengkap dan terperinci; 3) Perusahaan tersebut memiliki informasi tentang pengukuran variabel yang akan diteliti pada annual report dan financial report untuk tahun 2010 hingga 2017.

Bentuk data yang digunakan dalam riset ini berupa data panel yaitu gabungan antara data times series (periode waktu) dan data cross section (beberapa perusahaan yang telah dipilih menjadi sampel). Sumber data diperoleh dari Institut Pasar Modal Indonesia.
Teknik pengumpulan data yang digunakan adalah dokumentasi, dimana setelah dilakukan tenik purposisve sampling terdapat 51 perusahaan yang tergolong dalam sektor industri manufaktur dengan periode waktu mulai dari tahun 2010 hingga 2017 ( 8 tahun). Hal ini berarti total pengamatan untuk penelitian ini adalah sebanyak 408 yang diperoleh dari hasil perkalian antara periode waktu (8) dan jumlah perusahaan (51).

\section{Pengukuran Variabel Variabel Dependen}

Nilai perusahaan pada penelitian ini berperan sebagai variabel dependen, yang diukur berbasis nilai pasar yaitu tobin's q (Nguyen et al., 2015). Tobin's q merupakan perhitungan nilai pasar saham ditambah dengan total nilai hutang dibagi dengan total aset.

\section{Variabel Mediator}

Variabel mediasi dalam riset ini adalah kebijakan dividen yang diproksikan oleh DPR (dividend payout ratio). Kaźmierska-Jóźwiak (2015) menyatakan DPR adalah rasio pembayaran dividen yang dibagikan kepada para pemegang saham yang dapat dihitung dengan 
cara membandingkan DPS (dividend per share) dan EPS (earning per share).

\section{Variabel Independen}

Efektivitas keuangan yang berperan sebagai variabel eksogen dalam penelitian ini diproksikan oleh profitabilitas (ROA), dimana definisi operasional dari profitabilitas adalah kemampuan perusahaan untuk menghasilkan laba. ROA dapat dihitung dengan cara membagi laba setelah pajak (EAT) dengan total assetnya (Gugong et al., 2014).

Selain efektivitas keuangan, ukuran perusahaan juga berperan sebagai variabel eksogen dalam penelitian ini. Proksi dari ukuran perusahaan ini diukur oleh nilai buku total aset. Namun karena besarnya jumlah dari nilai aset perusahaan yang dihitung dalam jutaan rupiah maka diubah ke dalam logaritma natural (Setiadharma dan Machali, 2017), yaitu menjadi: Firm Size $=$ Ln TA

\section{Model Analisis}

Pengujian data pada penelitian ini menggunakan tehnik analisis SEM-PLS dengan software-nya yang disebut WarpPLS 5.0. Adapun model matematis untuk model empiris dari riset ini adalah sebagai berikut:

$\mathrm{DPR}_{\mathrm{it}}={ }_{1}+\beta_{1} \mathrm{ROA}_{\mathrm{it}}+\beta_{2} \mathrm{LnTA}_{\mathrm{it}}+\mathrm{e}_{1}$

Tobin $q={ }_{2}+\beta_{3} \mathrm{ROA}_{\mathrm{it}}+\beta_{4} \mathrm{LnTA}_{\mathrm{it}}+\beta_{5} \mathrm{DPR}_{\mathrm{it}}+\mathrm{e}_{2}$

\section{HASIL EMPIRIS}

Pengujian data dengan menggunakan SEMPLS yang tersebut di atas, memberikan goodness of fit (GoF) dari model penelitian ini. Adapun hasil output tersebut dapat dilihat pada tabel 1 berikut ini:

Tabel 1. Goodnes of Fit Model Structural (Kinerja Perusahaan = ROA)

\begin{tabular}{|c|c|}
\hline Kriteria & Parameter \\
\hline Average path coefficient (APC) & $0.365^{* * *}$ \\
\hline Average R-squared (ARS) & $0.606^{* * *}$ \\
\hline Average adjusted R-squared (AARS) & $0.603^{* * *}$ \\
\hline Average block VIF (AVIF) & 1.865 \\
\hline Average full collinearity VIF (AFVIF) & 1.592 \\
\hline Tenenhaus GoF (GoF) & 0.778 \\
\hline Sympson's paradox ratio (SPR) & 1.000 \\
\hline R-squared contribution ratio (RSCR) & 1.000 \\
\hline Statistical suppression ratio (SSR) & 1.000 \\
\hline Nonlinear bivariate causality direction ratio (NLBCDR) & 1.000 \\
\hline$* * *, * *, *$ denotes significance levels at $0.001,0.05$ and 0.1, respectively.
\end{tabular}

Berdasarkan tabel 1 di atas maka dapat dilihat model penelititan ini memiliki fit yang baik, dimana p-value untuk APC, ARS dan dan AAR $<0.001$ dengan nilai $\mathrm{APC}=0.365$, nilai $\mathrm{ARS}=$ 0.606 , dan nilai AARS $=0.603$. Demikian juga dengan nilai AVIF dan AFVIF yang dihasilkan yaitu $<3.3$, yang berarti tidak ada masalah multikolinieritas antar indikator dan antar variabel eksogen. GoF yang dihasilkan yaitu $0.778>0.36$ menunjukkan fit model yang sangat baik karena tergolong dalam kategori besar. SPR dan RSCR tergolong ideal karena memiliki nilai
1.000, SSR dan NLBCDR dapat diterima karena masing-masing memiliki nilai lebih dari 0.7 yaitu sebesar 1.000. Dengan demikian kriteria SPR, RSCR, SSR dan NLBCDR menunjukkan tidak adanya masalah kausalitas di dalam model (Latan dan Ghozali, 2017).

Kemudian untuk pengujian model struktural utama yang juga merupakan pengujian hipotesis dan sekaligus merupakan model empiris dari penelitian ini dapat dilihat pada gambar 2 berikut ini: 


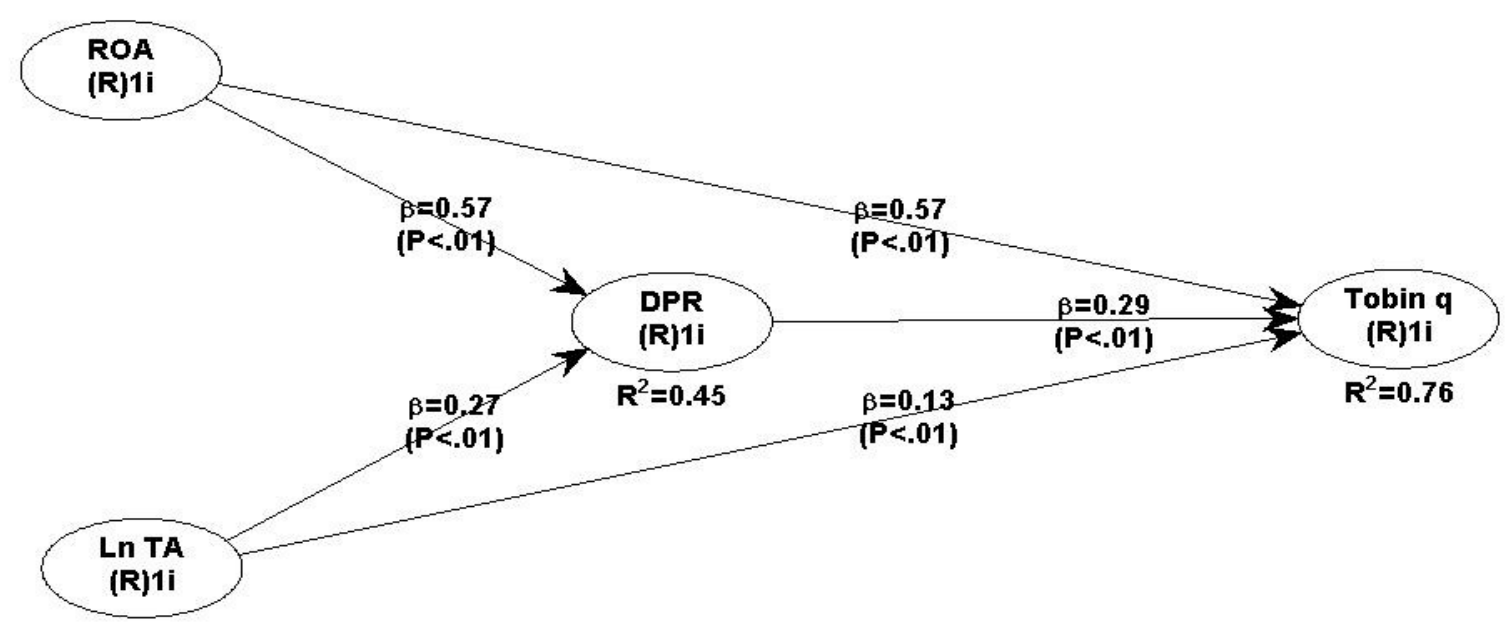

Gambar 2. Model Pengujian Hipotesis

Selanjutnya untuk melihat hasil estimasi hubungan antar konstruk serta besarnya variance dan effect size dapat dilihat pada tabel 2 berikut ini:

Tabel 2. Hasil Pengujian Model Struktural

\begin{tabular}{|l|l|l|l|l|l|}
\hline Description Path & $\begin{array}{l}\text { Path } \\
\text { Coefficient }\end{array}$ & Adj R & Q $^{2}$ & $\begin{array}{l}\text { Effect } \\
\text { Size }\end{array}$ & $\begin{array}{l}\text { Standar } \\
\text { Error }\end{array}$ \\
\hline ROA $\rightarrow$ DPR & $0.566^{*}$ & 0.448 & 0.449 & 0.350 & 0.046 \\
\hline Ln TA $\rightarrow$ DPR & $0.266^{*}$ & & & 0.100 & 0.048 \\
\hline ROA $\rightarrow$ Tobin q & $0.571^{*}$ & & & 0.482 & 0.046 \\
\hline Ln TA $\rightarrow$ Tobin q & $0.127^{* *}$ & & & 0.044 & 0.049 \\
\hline DPR $\rightarrow$ Tobin q & $0.294^{*}$ & 0.758 & 0.689 & 0.234 & 0.048 \\
\hline
\end{tabular}

$* * *, * *, *$ denotes significance levels at $0.001,0.05$ and 0.1 , respectively

All estimates influence between variables with a robust standard error.

Source: secondary data in though

Berdasarkan tabel 2 di atas, terlihat nilai adjusted $R$-squared $\left(\mathrm{R}^{2}\right)$ untuk variasi yang mempengaruhi kebijakan dividen (DPR) adalah sebesar 0.448. Nilai ini memberikan makna bahwa pengaruh variasi efektivitas keuangan (ROA) dan ukuran perusahaan (Ln TA) terhadap kebijakan dividen (DPR) adalah sebesar 44,8\% atau jika dibulatkan menjadi $45 \%$ dan sisanya $55 \%$ dipengaruhi oleh variabel lainnya yang ada di luar dari model penelitian ini. Berlandaskan pada rule of thumb evaluasi model struktural nilai variasi adjusted $R$-squared yang mempengaruhi kebijakan dividen (DPR) yaitu sebesar 0.448 , maka tergolong dalam kategori moderate $(\leq 0.45)$. Selanjutnya nilai adjusted $R$ squared $\left(\mathrm{R}^{2}\right)$ untuk variasi yang mempengaruhi nilai perusahaan (tobin's q) sebesar 0.758 memberikan gambaran bahwa variasi efektivitas keuangan (ROA), ukuran perusahaan (Ln TA), dan kebijakan dividen (DPR) terhadap variabel nilai perusahaan (Tobin q) adalah sebesar $75.8 \%$ atau $76 \%$ dan sisanya $24 \%$ dipengaruhi oleh variabel lain di luar dari model penelitian ini. Adapun nilai sebesar 0.758 ini termasuk dalam kategori kuat $(\leq 0.70)$ dan menunjukkan variasi yang dapat dijelaskan oleh variabel independen dan mediasi sebesar $75.8 \%$.

Nilai Q-squared yang dihasilkan oleh DPR dan Tobin q adalah $0.449>0$ dan $0.689>0$ yang berarti model memiliki validitas prediktif. Effect size dari variabel efektivitas keuangan (ROA) dengan nilai perusahaan (Tobin q) menghasilkan 0.571 . Mengacu pada tiga kategori effect size (Hair et al., 2013; Kock, 2013) yaitu lemah (0.02), medium (0.15), dan besar (0.35) maka efektivitas keuangan (ROA) tergolong 
memberikan effect size yang besar terhadap nilai perusahaan (tobin's q). Kemudian nilai effect size ukuran perusahaan (Ln TA) terhadap tobin's q sebesar 0.127 tergolong dalam kategori medium. Demikian juga untuk nilai effect size sebesar 0.294 dari kebijakan dividen (DPR) terhadap nilai perusahaan (Tobin's q) termasuk dalam kategori medium. Hal ini menyimpulkan bahwa nilai effect size yang terbesar dalam mempengaruhi nilai perusahaan adalah variabel efektivitas keuangan (ROA) sehingga dapat dinyatakan bahwa secara empiris efektivitas keuangan (ROA) memiliki peran penting dalam menentukan nilai perusahaan (tobin's q).

Hasil estimasi hubungan antar konstruk di atas, menunjukkan bahwa efektivitas keuangan (ROA) berpengaruh positif terhadap nilai perusahaan (tobin's q) dengan nilai koefisien jalurnya sebesar 0.571. Hasil ini menerima hipotesis 1. Dengan demikian, temuan ini mendukung hasil riset empiris (Sabrin et al., 2016; Rosikah et al., 2018; Ayuba et al., 2019) sebelumnya yang menyatakan bahwa efektivitas keuangan (ROA) berpengaruh positif terhadap nilai perusahaan (tobin's q).

Hasil estimasi hubungan antar konstruk untuk variabel efektivitas keuangan (ROA) terhadap kebijakan dividen (DPR) menunjukkan pengaruh yang positif dengan nilai koefisien jalur sebesar 0.566. Hasil ini menerima hipotesis 2. Dengan demikian, temuan ini mendukung hasil riset empiris (Abor dan Bokpin, 2010; Arko et al., 2014) sebelumnya yang menyatakan efektivitas keuangan (ROA) berpengaruh positif terhadap kebijakan dividen (DPR).

Hasil estimasi hubungan antar konstruk untuk variabel ukuran perusahaan (Ln TA) menunjukkan pengaruh yang positif terhadap nilai perusahaan (Tobin's q) dengan nilai koefisien jalur sebesar 0.127. Hasil ini mendukung hipotesis 4 sehingga sejalan dengan hasil riset empiris (Gill dan Obradovich, 2012; Prasetyorini, 2013; Pratama dan Wiksuana, 2016) sebelumnya yang menyatakan ukuran perusahaan (Ln TA) berpengaruh positif terhadap tobin's q.

Hasil estimasi hubungan antar konstruk untuk variabel ukuran perusahaan (Ln TA) terhadap kebijakan dividen (DPR) menunjukkan pengaruh yang positif dengan nilai koefisien jalur sebesar 0.266. Hasil ini menerima hipotesis 5. Dengan demikian, temuan ini mendukung hasil riset empiris sebelumnya (Aivazian et al., 2003; Ho, 2003) yang menyatakan bahwa ukuran perusahaan (Ln TA) berpengaruh positif terhadap kebijakan dividen (DPR).

Hasil estimasi hubungan antar konstruk untuk variabel kebijakan dividen (DPR) terhadap nilai perusahaan (tobin's q) menunjukkan pengaruh yang positf dengan nilai koefisien jalur sebesar 0.294. Hasil ini mendukung hipotesis 7 sehingga sejalan dengan riset empiris sebelumnya (Anton dan Cuza, 2016; Giriati, 2016) yang menyatakan kebijakan dividen (DPR) berpengaruh positif terhadap nilai perusahaan (tobin's q).

Selanjutnya untuk menguji hipotesis 3 (tiga) maka perlu dilakukan pengujian mediasi untuk membuktikan apakah kebijakan dividen (DPR) memediasi pengaruh efektivitas keuangan yang diproksikan oleh ROA (return on asset) terhadap nilai perusahaan yang diproksikan oleh tobin's q. Demikian juga untuk menguji hipotesis 6 maka perlu dilakukan pengujian mediasi untuk mengungkapkan apakah kebijakan dividen (DPR) memediasi pengaruh ukuran perusahaan (Ln TA) terhadap nilai perusahaan (Tobin's q). Untuk itu, pengujian mediasi pada riset yang dilakukan ini menggunakan metode VAF (variance accounted for). Hal ini mengacu pada pendapat Hair et al. (2013) yang menyatakan bahwa metode VAF dipandang lebih sesuai dan tepat dari metode lainnya untuk menguji mediasi dalam SEM-PLS.

Prosedur pengujian mediasi dengan metode ini terdiri dari 3 tahapan, yaitu: pertama, menguji pengaruh langsung variabel eksogen terhadap variabel endogen tanpa memasukkan variabel mediasi; kedua, jika pengaruh langsung variabel eksogen terhadap variabel endogen adalah signifikan maka dapat dilanjutkan dengan menguji pengaruh tidak langsung variabel eksogen terhadap variabel endogen dengan memasukkan variabel mediasi; ketiga, jika pengaruh tidak langsung dari variabel eksogen terhadap variabel endogen adalah signifikan maka langkah selanjutnya adalah menghitung besarnya nilai VAF untuk menentukan efek 
mediasi dengan kriteria sebagai berikut: a) VAF $>80 \%$ berarti memediasi penuh (full mediation); b) $20 \% \leq \mathrm{VAF} \leq 80 \%$ berarti memediasi sebagian (partial mediation); c) $\mathrm{VAF}<20 \%$ berarti tidak ada efek mediasi.
VAF dapat dihitung dengan cara membagi indirect effect dengan total effects. Untuk mengetahui seberapa besar nilai indirect effect dan total effect serta koefisien signifikansi dapat dilihat pada hasil output indirect dan total effect, sebagaimana terangkum pada tabel 3 berikut ini.

Tabel 3. Output Indirect, Total Effect dan P-value

\begin{tabular}{|c|c|c|c|c|}
\hline \multicolumn{5}{|c|}{ Indirect effects for paths with 2 segments } \\
\hline & ROA & Ln TA & DPR & Tobin $\mathrm{q}$ \\
\hline \multicolumn{5}{|l|}{ ROA } \\
\hline \multicolumn{5}{|l|}{ Ln TA } \\
\hline \multicolumn{5}{|l|}{ DPR } \\
\hline Tobin $\mathrm{q}$ & 0.167 & 0.078 & & \\
\hline \multicolumn{5}{|c|}{$P$ values of indirect effects for paths with 2 segments } \\
\hline & $\mathrm{ROA}$ & Ln TA & DPR & Tobin $\mathrm{q}$ \\
\hline \multicolumn{5}{|l|}{$\mathrm{ROA}$} \\
\hline \multicolumn{5}{|l|}{ Ln TA } \\
\hline \multicolumn{5}{|l|}{ DPR } \\
\hline Tobin $\mathrm{q}$ & $<0.001$ & 0.012 & & \\
\hline \multicolumn{5}{|c|}{ Total effects } \\
\hline & ROA & Ln TA & DPR & Tobin $\mathrm{q}$ \\
\hline \multicolumn{5}{|l|}{ ROA } \\
\hline \multicolumn{5}{|l|}{ Ln TA } \\
\hline DPR & 0.566 & 0.266 & & \\
\hline Tobin $\mathrm{q}$ & 0.737 & 0.205 & 0.294 & \\
\hline \multicolumn{5}{|c|}{ P values for total effects } \\
\hline & ROA & Ln TA & DPR & Tobin $\mathrm{q}$ \\
\hline \multicolumn{5}{|l|}{$\mathrm{ROA}$} \\
\hline \multicolumn{5}{|l|}{ Ln TA } \\
\hline DPR & $<0.001$ & $<0.001$ & & \\
\hline Tobin $\mathrm{q}$ & $<0.001$ & $<0.001$ & $<0.001$ & \\
\hline
\end{tabular}

Mengacu pada tabel 3 di atas, maka dapat dihitung VAF pengaruh efektivitas keuangan dan ukuran perusahaan terhadap nilai perusahaan melalui kebijakan dividen sebagai pemediasi seperti yang terlihat pada tabel 4 berikut:

Tabel 4. Perhitungan VAF untuk Pengaruh Efektivitas Keuangan dan Ukuran Perusahaan terhadap Nilai Perusahaan melalui Kebijakan Dividen sebagai Variabel Mediasi

\begin{tabular}{|c|c|c|c|}
\hline \multicolumn{2}{|c|}{$\begin{array}{c}\text { DPR sebagai Pemediasi untuk ROA terhadap } \\
\text { Tobin's q }\end{array}$} & $\begin{array}{c}\text { DPR sebagai Pemediasi untuk Ln TA terhadap } \\
\text { Tobin's q }\end{array}$ \\
\hline Indirect effect & 0.167 & Indirect effect & 0.078 \\
\hline Total Effect & 0.737 & Total effect & 0.205 \\
\hline $\begin{array}{c}\text { VAF (Indirect } \\
\text { effect/total effect) }\end{array}$ & 0.226 & $\begin{array}{l}\text { VAF (indirect } \\
\text { effect/total effect) }\end{array}$ & 0.381 \\
\hline
\end{tabular}


Berdasarkan tabel 4 di atas maka diketahui nilai VAF sebesar 0.226 atau $22.6 \%$ dari DPR sebagai pemediasi untuk efektivitas keuangan terhadap Tobin's q. Hasil tersebut mengindikasikan bahwa kebijakan dividen memediasi secara parsial $(20 \% \leq \mathrm{VAF} \leq 80 \%)$ pengaruh efektivitas keuangan terhadap nilai perusahaan. Demikian juga, DPR sebagai pemediasi untuk ukuran perusahaan (Ln TA) terhadap nilai perusahaan yang diproksikan oleh Tobin's q tergolong dalam mediasi sebagian atau parsial yang ditunjukkan dari nilai VAF-nya sebesar 0.381 atau $38.1 \%$. Secara keseluruhan hasil VAF ini menunjukkan kebijakan dividen memediasi secara parsial pengaruh efektivitas keuangan dan ukuran perusahaan terhadap nilai perusahaan. Artinya, pengaruh efektivitas keuangan dan ukuran perusahaan terhadap nilai perusahaan akan lebih besar jika merupakan pengaruh tidak langsung daripada pengaruh langsung. Oleh karena itu, dapat disimpulkan bahwa efektivitas keuangan dan ukuran perusahaan mampu meningkatkan nilai perusahaan melalui optimalisasi kebijakan dividen.

\section{KESIMPULAN}

Studi ini bertujuan untuk menguji secara empiris kontribusi dari kebijakan dividen dalam memediasi pengaruh efektivitas keuangan dan ukuran perusahaan terhadap nilai perusahaan. Hasil pengujian menunjukkan bahwa kebijakan dividen memediasi secara parsial pengaruh efektivitas keuangan dan ukuran perusahaan terhadap nilai perusahaan. Dengan demikian, efektivitas keuangan dan ukuran perusahaan akan dapat meningkatkan nilai perusahaan dengan meningkatkan kebijakan dividennya.

\section{DAFTAR PUSTAKA}

Abor, J., dan G. A. Bokpin. 2010. "Investment opportunities, corporate finance, and dividend payout policy: Evidence from emerging markets". Studies in Economics and Finance, Vol. 27, No. 3, hlm: 15.

Aivazian, V., L. Booth, dan S. Cleary. 2003. "Do emerging market firms follow different dividend policies from US firms?". Journal of financial Research, Vol. 26, No. 3, hlm: 371-387.

Amidu, M., dan J. Abor. 2006. "Determinants of dividend payout ratios in Ghana". The journal of risk finance, Vol. 7, No. 2, hlm: 136-145.

Anton, S. G., dan A. I. Cuza. 2016. "The Impact of Dividend Policy on Firm Value. A Panel Data Analysis of Romanian Listed Firms". Journal of Public Administration, Finance and Law, Vol., No. 10, hlm: 107-112.

Ardestani, H. S., S. Z. A. Rasid, dan R. B. M. Mehri. 2013. "Dividend payout policy, investment opportunity set and corporate financing in the industrial products sector of Malaysia". Journal of Applied Finance and Banking, Vol. 3, No. 1, hlm: 123.

Arko, A. C., J. Abor, C. K. D. Adjasi, dan M. Amidu. 2014. "What influence dividend decisions of firms in Sub-Saharan African?". Journal of accounting in emerging economies, Vol. 4, No. 1, hlm: 57-78.

Ayuba, H., A. J. a. Bambale, M. A. Ibrahim, dan S. A. Sulaiman. 2019. "Effects of Financial Performance, Capital Structure and Firm Size on Firms' Value of Insurance Companies in Nigeria". Journal of Finance, Accounting \& Management, Vol. 10, No. 1, hlm.

Carlson, S. J., dan C. T. Bathala. 1997. "Ownership differences and firms' income smoothing behavior". Journal of Business Finance \& Accounting, Vol. 24, No. 2, hlm: 179-196.

Carningsih. 2008. "Pengaruh GCG terhadap Hubungan antara Kinerja Keuangan dengan Nilai Perusahaan". Vol., No., hlm.

Chen, C. R., dan T. L. Steiner. 2000. "Tobin'sq, managerial ownership, and analyst coverage: A nonlinear simultaneous equations model". Journal of Economics and Business, Vol. 52, No. 4, hlm: 365382.

Chen, L. J., dan S. Y. Chen. 2011. "The Influence of Profitability on Firm Value with Capital Structure as The Mediator and Firm Size and Industry as Moderators". Investment Management and Financial Innovation, Vol. 8, No. 3, hlm.

Fama, E. F., dan K. R. French. 1998. "Taxes, financing decisions, and firm value". The Journal of Finance, Vol. 53, No. 3, hlm: 819-843.

Ghozali, I. 2020. 25 Grand Theory. 
Gill, A., dan J. Obradovich. 2012. "The impact of corporate governance and financial leverage on the value of American firms". International Research Journal of Finance and Economics, Vol., No. 91, hlm.

Giriati, Z. 2016. "Free cash flow, dividend policy, investment opportunity set, opportunistic behavior and firm's value:(A study about agency theory)". Procedia-Social and Behavioral Sciences, Vol. 219, No., hlm: 248-254.

Gugong, B. K., L. O. Arugu, dan K. I. Dandago. 2014. "The impact of ownership structure on the financial performance of listed insurance firms in Nigeria". International journal of academic research in accounting, finance and management sciences, Vol. 4, No. 1, hlm: 409-416.

Hair, J. F., C. M. Ringle, dan M. Sarstedt. 2013. "Partial least squares structural equation modeling: Rigorous applications, better results and higher acceptance". Long range planning, Vol. 46, No. 1-2, hlm: 112.

Hermuningsih, S. 2014. "Profitability, growth opportunity, capital structure and the firm value". Buletin Ekonomi Moneter dan Perbankan, Vol. 16, No. 2, hlm: 115136.

Ho, H. 2003. "Dividend policies in Australia and Japan". International Advances in Economic Research, Vol. 9, No. 2, hlm: 91-100.

Iswajuni, I., A. Manasikana, dan S. Soetedjo. 2018. "The effect of enterprise risk management (ERM) on firm value in manufacturing companies listed on Indonesian Stock Exchange year 20102013". Asian Journal of Accounting Research, Vol., No., hlm.

Jensen, M. C., dan W. H. Meckling. 1976. "Theory of The Firm: Managerial Behavior, Agency Costs and Ownership Structure". Journal of Financial Economics, Vol. 3, No., hlm: 305-360.

Kaaro, H. 2002. "Investment Decision and Dividend Policy as Determinants of Financing Decision: A New Empirical Evidence". Journal of Accounting, Management, and Economic Research (JAMER), Vol. 2, No. 1, hlm: 16.

Kaźmierska-Jóźwiak, B. 2015. "Determinants of Dividend Policy: Evidence from Polish
Listed Companies". Procedia Economics and Finance, Vol. 23, No., hlm: 473-477.

Kock, N. 2013. "Using WarpPLS in ecollaboration studies: What if I have only one group and one condition?". International Journal of e-Collaboration (IJeC), Vol. 9, No. 3, hlm: 1-12.

Kodongo, O., T. Mokoaleli-Mokoteli, dan L. N. Maina. 2015. "Capital structure, profitability and firm value: panel evidence of listed firms in Kenya". African Finance Journal, Vol. 17, No. 1, hlm: 1-20.

Latan, H., dan I. Ghozali. 2017. Partial Least Squares: Konsep, Metode dan Aplikasi menggunakan Program WarpPLS 5.0 (Third Edit).

Leland, H. E., dan D. H. Pyle. 1977. Informational asymmetries, financial structure, and financial intermediation. In The Journal of Finance, 371-387.

Livoreka, B., A. Hetemi, A. Shala, A. Hoti, dan R. Asllanaj. 2014. "Theories on Dividend Policy Empirical Research in Joint Stock Companies in Kosovo". Procedia Economics and Finance, Vol. 14, No., hlm: 387-396.

López-Iturriaga, F. J., dan J. A. RodríguezSanz. 2001. "Ownership structure, corporate value and firm investment: A simultaneous equations analysis of Spanish companies". Journal of Management and Governance, Vol. 5, No. 2, hlm: 179-204.

Megginson, W. L. 1997. Corporate finance theory: Addison-Wesley.

Nguyen, T., S. Locke, dan K. Reddy. 2015. "Ownership concentration and corporate performance from a dynamic perspective: Does national governance quality matter?". International review of financial analysis, Vol. 41, No., hlm: 148-161.

Pattiruhu, J. R., dan M. PAAIS. 2020. "Effect of liquidity, profitability, leverage, and firm size on dividend policy". The Journal of Asian Finance, Economics, and Business, Vol. 7, No. 10, hlm: 35-42.

Prasetyorini, B. F. 2013. "Pengaruh Ukuran Perusahaan, Leverage, Price Earning Ratio dan Profitabilitas terhadap Nilai Perusahaan". Jurnal Ilmu Manajemen, Vol. 1, No. 1, hlm: 183-196.

Pratama, I. G. B. A., dan I. G. B. Wiksuana. 2016. "Pengaruh Ukuran Perusahaan dan Leverage terhadap Nilai Perusahaan dengan Profitabilitas sebagai Variabel 
Mediasi". E-Jurnal Manajemen Unud, Vol. 5, No. 2, hlm: 1338-1367.

Rizki, Z. W., D. Mochammad, dan R. S. Mangesti. 2018. "The Effect of profitability, liquidity on capital structure and firm value: A Study of Property and Real Estate Companies Listed on Indonesia Stock Exchange in 2013-2015". EURASIA: Economics \& Business, Vol. 8, No. 2, hlm: 34-41.

Rosikah, D. K. P., D. A. Muthalib, M. I. Aziz, dan M. Rohansyah. 2018. "Effect of Return On Asset, Return On Equity, Earning Per Share Corporate Value". The International Journal of Engineering and Science (IJES). ISSN, Vol., No., hlm: 2319-1813.

Sabrin, B. Sarita, D. T. S, dan Sujono. 2016. "The effect of profitability on firm value in manufacturing company at Indonesia Stock Exchange". The International Journal of Engineering and Science, Vol. 5, No. 10, hlm: 81-89.

Sartono, R. A. 2014. Manajemen keuangan teori dan aplikasi. 4 ed. Yogyakarta: BPFE.

Setiadharma, S., dan M. Machali. 2017. "The effect of asset structure and firm size on firm value with capital structure as intervening variable". Journal of Business \& Financial Affairs, Vol. 6, No. 4, hlm: 1-5.

Spence, M. 1973. "Job market signaling". Quarterly Journal of Economics, Vol., No., hlm: 355-374.

Sucuahi, W., dan J. M. Cambarihan. 2016. "Influence of Profitability to the Firm Value of Diversified Companies in the Philippines". Accounting and Finance Research, Vol. 5, No. 2, hlm.

Suharli, M. 2006. "Studi Empiris terhadap Faktor yang Mempengaruhi Nilai Perusahaan pada Perusahaan Go Public di Indonesia". MAKSI, Vol. 6, No., hlm.

Suranta, E., dan P. P. Merdistuti. 2004. "Income smoothing, Tobin's $\mathrm{Q}$, agency problems dan kinerja perusahaan". Simposium Nasional Akuntansi VII, Vol., No., hlm.

Tamrin, M., H. R. Mus, dan A. Arfah. 2017. "Effect of profitability and dividend policy on corporate governance and firm value: Evidence from the Indonesian manufacturing Sectors". IOSR Journal of Business and Management (IOSR-JBM), Vol. 19, No. 10, hlm: 66-74.
Uchida, K. 2006. Agency costs of debt and the relationship between firm performance and managerial ownership: Evidence from Japan. The Society for Economic Studies. The University of Kitakyushu. Working Paper Series.

Wajeetongratana, P., T. Sriyakul, dan K. Jermsittiparsert. 2019. "Financial effectiveness, investment efficiency, and quality of financial reporting: Evidence from ASEAN states". International Journal of Innovation, Creativity and Change, 8 (8), 334, Vol. 350, No., hlm. 